\title{
Pemberian Sanksi Pidana Bagi Pelaku Penyebaran Hoax Ditinjau Dari Aspek Tindak Pidana Terorisme
}

\section{Grating Criminal Sanctions For The Performers Of Hoax Spreading Reviewed From The Aspect Of Criminal Action Af Terrorism}

\author{
Afdal Junaidi*, Triono Eddy \& Alfi Sahari \\ Program Magister Ilmu Hukum, Universitas Muhammadiyah Sumatera Utara, Indonesia. \\ Diterima: 31 Agustus 2020; Direview: 29 September 2020; Disetujui: 10 Oktober 2020
}

*Coresponding Email: afdaljailani588@gmail.com

\begin{abstract}
Abstrak
Penelitian ini merupakan penelitian hukum normatif, bersifat deskriptif analisis, dengan pendekatan perundang-undangan, pendekatan konseptual, serta pendekatan kasus. Tujuan dari pada penelitian ini adalah untuk menganalisis bentuk penyebaran berita bohong dalam perundang-undangan di Indonesia dan sanksi pidana bagi pelaku penyebaran berita bohong ditinjau dari aspek tindak pidana terorisme. Hasil penelitian ini menunjukkan bahwa bentuk penyebaran berita bohong dapat dikategorikan sebagai tindak pidana terorisme, dimana tindak pidana terorisme adalah juga mengancam keselamatan bangsa dan negara, menimbulkan perpecahan, membuat kegaduhan dimasyarakat, meskipun tindakan penyebaran berita bohong tersebut tidak diatur dalam undang-undang terorisme namun menimbulkan efek yang mungkin sama dengan yang dilakuakn oleh para terorisme, hanya saja perbuatan penyebaran berita bohong tersebut tidak mengancam nyawa banyak orang. Bahwa sanksi pidana bagi pelaku penyebaran berita bohong (berita bohong) ditinjau dari aspek tindak pidana terorisme adalah dapat disamakan dengan pemidanaan permufakatan jahat, percobaan, dan pembantuan untuk melakukan tindak pidana terorisme.
\end{abstract}

Kata Kunci: Sanksi Pidana,Pelaku, Hoax, Terorisme

\begin{abstract}
This research, descriptive analysis, with a statutory approach, conseptual approach. The purpose of this research is to analyze the from of spreading fake news in Indonesia legislation and criminal sactions for the perpetrators of spreading fake news in term of the criminal act of terrorism. The results of this study indicate that the form of spreading fake news can be categorized as criminal act of terrorism, where the criminal act of terrorism is also threatening the safety of the nation and the state, causing divisions, causing uproar in the community, even though the act of spreading fake news is not regulated in the terrorism law but causes the effect that may be the same as that of terrorism, it's just that the act of spreading fake news does not threaten the lives of many people. Whereas the criminal sanction for the perpetrators of spreading fake news inthe terms of the aspect of the criminal act of terrorism are equivalent to the convictions of criminal conspiracy, attempted and assisting in committing the crime of terrorism.
\end{abstract}

Keywords: Criminal Sanctions, Perpetrators, Hoaxes, Terrorism

How to Cite: Junaidi, A., Eddy, T., \& Sahari, A. (2020).Tanggung Jawab Notaris Atas Perbuatan Klien yang Mengandung Unsur Pemalsuan dalam Proses Pembuatan Akta. Journal of Education, Humaniora and Social Sciences (JEHSS). 3(2): 401-411 


\section{PENDAHULUAN}

Teknologi informasi memiliki peran yang sangat penting, baik di masa kini maupun masa depan. Teknologi informasi diyakini akan membawa keuntungan dan kepentingan yang besar bagi negara-negara di dunia (Raharjo, 2002). Pada awalnya teknologi informasi diharapkan mampu untuk mencioptakan kemudahan dan kesejahteraan bagi masyarakat secara umum, seperti yang diketahui bahwa teknologi yang sekarang berkembang pesat dizaman modern ini adalah internet.

Perkembanagan internet di dunia saat iini sangatlah termasuk di Indonesia. Apalagi kemudian setelah munculnya teknologi telepon pintar dengan segala aplikasi baik dalam bentuk media sosial maupun yang lainnya. Penggunaaan telepon pintar juga beragam, dari anak-anak sampai dengan orang dewasa, dengan berbagai latar belakang ekonomi (Sitompul, 2004). Internet sebagai media kekinian adalah media yang tidak mengenal batas, baik batas wilayah maupun batas kenegaraan internet tentu saja membawa dampak positif dan negatif bagi pemakainya. Seperti yang diketahui peraturan teraturan terkait dengan perilaku yang dianut setiap negara berbeda-beda, sehingga apa yang boleh dilakukan secara bebas di suatu negara akan dianggap pelanggaran hukum di negara lain, dengan demikian pula sebaliknya. Pada sisi lai, internet tidak mengenal batas negara. Misalnya seorang pengguna internet Indonesia yang masuk kesatu situs yang tidak ada bedanya dengan pengguna dari negara lain yang masuk kesitus yanga sama (Sidiq, 2017) sesuai dengan anamnya World Wide Web (www), maka jaringan internet ini selebar dunia. Hukum yang dibuat untuk mengatur internet di suatu negara dengan segera dan dengan sendirinya akan masuk wilayah jurisdiksi negara lain. Hal ini tentu saja akan terjadi pertentangan, apa yang di larang di Indonesia kemungkinan diwajibkan di negara lain.

Salah satu fasilitas yang tersedia di internet adalah media sosial, semisal facebok, whatsaap, line, instagram dan banyak media sosial lainnya. Sementara media sosial memiliki dua sisi, disatu sisi media sosial dapat menjangkau seluruh lapisan masyarakat sehingga mudah untuk berkomunikasi, akan tetapi pada sisi lain semua orang melalui media sosial dengan mudahnya untuk menyebarkan berita yang tidak benar berupa, fitnah, pencemaran nama baik, penghinaan, ujaran kebencian dan khususnya penyebaran berita bohong (hoax) yang paling banyak terjadi sehingga menyebabkan masyarakat ikut terprovokasi untuk memecah belah bangsa (Novitawati Dkk., 2019).

Penyebaran berita bohong marak terjadi ketika adanya kontestasi pemilu baik pilkada, pileg, maupun pilpres, dengan memberikan berita-berita tidak benar, sehingga menyesatkan serta memengaruhi pola pikir masyarakat terkait sosok seorang yang sedang menjalani kontestasi pemilu (Nugroho \& Mursid, 2019). Bukan hanya sampai disitu, ternyata motif pembuatan berita bohong adalah beragam dari perbuatan iseng hingga menyudutkan pemimpin bangsa (Octaviyani, 2019) berita bohong juga terkait dengan informasi tentang bencana alam, misalnya adanya gempa dengan kekuatan besar terjadi di daerah tertentu, padahal gempa itu tidak terjadi sama sekali. Penyebaran berita bohong yang semakin meluas akhirnya mengakibatkan nama baik dan harga diri seorang menjadi rusak serta berpotensi meningkatkan konflik berbau SARA dimasyarakat, dan berita bohong termasuk menjadi salah satu faktor kemunduran suatu negara. Karena masyarakat menjadi resah dan mudah terprovokasi dengan berita palsu, sehingga hal tersebut yang menjadi penyebab utama berita bohong mudah memengaruhi masyarakat (Hidayat et al., 2020; Nasution, 2015).

Literasi masyarakat begitu rendah saat memfilter informasi yang ada di media sosial, mengakibatkan masyarakat menjadi terpola menjadi beberapa bagian. Hal ini tentunya berakibat terjadinya perpecahan anak bangsa, perbedaan bangsa yang seharusnya disikapi secara arif dan bijaksana, pada akhirnya akan muncul kericuhan. Kasus berita bohong yang paling viral adalah 
kasus Jonru Ginting yaitu seorang penulis, narablog, dan pengusaha yang dikenal karena usahanya self publishing dapur buku.com dimana Jonru terbukti melanggar Pasal 28 ayat 2 Juncto Pasal 45A ayat 2 Undang-Undang Nomor 19 Tahun 2016 Tentang Perubahan atas UndangUndang Republik Indonesia Nomor 11 Tahun 2008 tentang Informasi dan Transaksi Ekonomi juncto Pasal 65 ayat 1 KUHP. Jaksa Penuntut Umum menyebut serangkaian informasi yang disebut menimbulkan kebencian itu diunggah Jonru dalam akun facebook miliknya. Dampak membahayakan bagi keselamatan bangsa disebabkan bahaya berita bohong tersebut, maka beberapa petinggi negara mengusulkan agar pelaku penyebaran berita bohong didakwa melanggar Undang-Undang Terorisme. Adanya usulan tersebut didasarkan pada akibat yang ditimbulkan dari berita bohong yang dianggap sama dengan bahaya terorisme, yaitu mengancam keselamatan masyarakat banyak dan penyebar berita bohong tersebut sebagai peneror masyarakat.

Berdasarkan hal tersebut diatas jika dilihat dari kaca mata defenisis terorisme, maka berita bohong tersebut dapat disebut sebagai terorisme. Terorisme dalam undang-undang terorisme secara harfiah dimaknai dengan segala sesuatu yang sifatnya meresahkan banyak orang. Dimana efek dari berita bohong tersebut sangat buruk, terjadi perpecahan di masyarakat, perdebatan yang tak kunjung usai, saling memaki, saling caci, sehingga banyak persahabatan dan rasa persaudaraan yang terputus. Akan tetapi sangat keliru jika diartikan bahwa penyebaran berita bohong tersebut dinyatakan melanggar Undang-Undang terorisme, karena tidak relevan dengan nilai-nilai filosofis dan tujuan lahirnya undang-undang terorisme, hal ini tidaklah mudah bagi penegak hukum baik itu polisi, jaksa dan hakim, dimana diketahui bahwa tindak pidana terorisme dan tindak pidana yang melanggar undang-undang ITE adalah dua hal yang berbeda. Berdasarkan latar belakang diatas maka penulis tertarik untuk melakukan penelitian dengan judul pemberian sanksi pidana bagi pelaku penyebaran hoax ditinjau dari aspek tindak pidana terorisme.

\section{METODE PENELITIAN}

Metode yang digunakan dalam dalam penelitian ini adalah penelitian hukum normatif yang bersifat kualitatif. Hal ini disebabkan data yang dianalisis bersifat menyeluruh dan merupakan suatu kesatuan yang bulat (holistik), dimana keanekaragaaman datanya harus didukung dengan informasi yang mendalam (indepth information) (Mendelson, 1979). Menurut Bismar Nasution berpendapat bahwa penelitian hukum normatif adalah penelitian yang mengacu pada normanorma hukum yang terdapat dalam peraturan perundang-undangan dan putusan pengadilan. (Bismar, 2003) pendekatan yang digunakan dalam penelitian ini adalah studi perbandingan (comparative study). Penelitian ini mengkaji dan meneliti mengenai produk-produk hukum.

\section{HASIL DAN PEMBAHASAN}

\section{Berita Bohong (Hoax) dalam Perspektif Peraturan Perundang-undangan di Indonesia}

Perkembangan teknologi dan komunikasi sekarang ini memungkinkan setiap orang untuk menyebar informasi kapanpun dan dimanapun termasuk berita bohong atau hoax. Tak jarang untuk kepentingan tertentu sebuah informasi keliru atau yang disebut hoax marak bermunculan. Tidak jarang sebuah gambar disertai dengan tajuk yang mengejutkan yang tidak bisa dijamin kebenarannya. Keterangannya pun banyak memunculkan perselisihan. Dengan adanya aplikasi google image memudahkan setiap orang mendapatkan sebuah gambar, apakah gambar itu sebuah rekayasa atau sebuah fakta. Untuk kepentingan tertentu tak jarang sebuah foto diunggah dengan pemberitaan keliru.

Belakangan ini sering terjadi pemberitaan tidak benar, khususya di jejaring media sosial online. Penyebaran berita berita bohongmakin mengkhawatirkan, peyebaran berita bohong tidak hanya membodohi masyarakat, namun tindakan itu juga dipakai pihak-pihak tertentu untuk membangkitkan emosi masyarakatagar terjadi perpecahan di masyarakat, pada akhirnya akan 
menghancurkan persatuan bangsa (Sisworo, 2017) Hoax bukanlah merupakan suatu singkatan, melainkan kata dalam Bahasa Inggris yang berarti: tipuan, menipu, berita bohong, berita palsu atau kabarburung. Dengan kata lain dapat diartikan bahwa hoax merupakan kata yangmengandung arti ketidakbenaran suatu informasi. Jika dilakukan di dalamUndang-Undang tidak satupun yang akan menemukan kata "hoax" yangselanjutnya dapat dikualifikasi sebagai perbuatan pidana. Sebagai suatu tindakperbuatan maka potensi mengakibatkan pelanggaran terhadap kepentingan hokumberupa: kepentingan hukum perseorangan dan kepentingan hukum kolektif ( yaitu terhadap masyarakat atau negara).

Menurut Firmansyah, hoax adalah berita yang sengaja dibuat untuk menyesatkan pembaca. Ada dua motivasi utama penyebab berdarnya berita palsu atau hoax. Pertama adalah uang, artikel berita seolah-olah menjadi virus diberbagai media, yang dapat menarik pendapat iklan yang signifikan saat pengguna menklik situs tersebut. Maka tak heran jika dalam penyebaran berita hoax lebih banyak disebarkan melalui media sosial. Adapun motivasi yang kedua adalah ideologis. Beberapa penyedia berita palsu berusaha untuk memajukan kandidat yang mereka sukai (Ricky, 2017). Secara singkat berita bohong dalam bahasa Indonesia dikenal dengan nama berita bohong.Berita bohong adalah hasil akhir dari berita yang direkayasa melalui proses perekayasaan berita (Pareno, 2005). Berita bohong adalah informasi sesat dan berbahaya karena menyesatkan persepsi manusiadengan menyampaikan informasi palsu sebagai kebenaran. Berita bohong atau berita bohong mampu mempengaruhi banyak orang dengan menodai suatu citra dan kredibilitas. Berita bohong dapat bertujuan untuk mempengaruhi pembaca dengan informasi palsu sehingga pembaca mengambil tindakan sesuai dengan isi berita palsu. Sebagai pesan informasi palsu dan menyesatkan, hoax juga dapat menakut-nakuti orang yang membacanya (Rasywir, 2016)

Berita bohong pada umumnya terdapat di media sosial seperti facebook, whatsapp, line, instagram, sehingga dapat dengan mudah diakses oleh khalayak umum di berbagai telepon pintar.Berita bohong juga banyak beredar diberbagai media online. Media online bersifat mudah di share (dibagikan) dengan memanfaatkan saluran media sosial (medsos) akan melahirkan dampak yang lebih luas, jika pada saluran pertama yakni penyedia informasi melakukan pelanggaran etika pers atau melakukan perbuatan pidana atau delik pers. Dewan Pers yang merupakan lembaga yang berperan menyehatkan pers, dari sisi kewenangannya pun masih lemah karena hanya bersifat melakukan pemantauan dan pendataan. Di sisi lainnya, potensi pelanggaran seperti pencemaran nama baik (character assassination) sangat mungkin terus berlanjut (Detlor \& Tumbull, 1999).

Media sosial saat ini dipenuhi dengan beragam Hoax, isu-isu SARA, ujaran kebencian (hate speech), provokasi, fitnah, sikap intoleran, anti Pancasila dan keadaannya cukup memprihatinkan, dimana akhir-akhir ini penyebaran Hoax, ujaran kebencian, isu SARA, dan bentuk-bentuk intoleransi lainnya begitu luas tersebar di jejaring media sosial, bahkan mulai mengancam keutuhan bangsa. Selain media sosial, tidak sedikit pula media mainstream (cetak dan digital) yang terjebak dalam Hoax, bahkan ada yang menebarkan berita dan informasi palsu sebagai tujuan politik (Rahmatullah, 2018).

Umumnya berita bohong bertujuan untuk bercanda sekedar untuk mendapat kesenangan saja. Kenyataannya berita bohongdijadikan alat propaganda dengan tujuan politis, misalnya melakukan pencitraan atau sebaliknya, memburukkan citra seseorang atau kelompok. Banyak ditemukan berita bohong (berita bohong) dijadikan berita yang menghasut, memberikan ramalan-ramalan, bahkan untuk menyudutkan pemerintah. Berita bohong juga bertujuan membuat pikiran siapapun pembacanya ke arah yang menyesatkan. Berita bohong merupakan contoh negatif kebebasan berbicara dan berpendapat dimedia sosial. Dengan mudahnya menyebarkan berita bohongyang membuat siapapun bisa melakukan perbuatan ini, berita bohong menjadi salah satufenomena kejahatan dunia maya yang mengkhawatirkan (Sisworo:2009). Kamus hukum sendiri kata "berita" dapat diartikan sebagai suatu laporan 
mengenai kejadian atau peristiwa yang hangat, kabar dan suatu informasi terutama yang resmi seperti laporan pers. Sedangkan kata "bohong" adalah sesuatu yang tidak sesuai dengan hal atau keadaan yang sebenarnya sehingga juga dapat diartikan sebagai dusta. Bukan yang sebenarnya ini dengan kata lain adalah palsu biasanya mengenai suatu permintaan (Sudarsono, 2007).

Penyebaran berita bohong (hoax) merupakan suatu kejahatan yang konvensional. Kejahatan konvensional adalah suatu kejahatan terhadap jiwa, harta benda, dan kehormatan yang menimbulkan kerugian baik fisik maupun psikis yang baik dilakukan dengan cara-cara biasa maupun dimensi baru, yang terjadi di dalam negeri. Kejahatan konvensional merupakan kejahatan dengan isu paling mendasar dan sering terjadi di masyarakat, memiliki lingkup lokal dan meresahkan masyarakat. Bentuk kejahatan tersebut diantaranya perjudian,pencurian kekerasan/pemberatan, pencurian kendaraan bermotor, penganiayaa, pembunuhan, perkosaan, penipuan, pemalsuan, penculikan, dan pemerasan (Basaria, 2017).

Besarnya efek yang disebabkan oleh berita bohong tersebut, maka pemerintah membuat regulasi yang dapat menjerat pelaku berita bohong dengan sanksi pidana.Berita bohongatau berita bohong diatur dalam pasal 28 Undang-Undang Nomor 11 Tahun 2008 tentang Informasi dan Transaksi Elektronik. Pasal 28 Undang-Undang Nomor 11 Tahun 2008 Tentang Informasi dan Transaksi Elektronik berbunyi: 1) Setiap Orang dengan sengaja, dan tanpa hak menyebarkan berita bohong dan menyesatkan yang mengakibatkan kerugian konsumen dalam Transaksi Elektronik; 2) Setiap orang dengan sengaja dan tanpa hak menyebarkan informasi yang ditujukan untuk menimbulkan rasa kebencian atau permusuhan individu dan/atau kelompok masyarakat tertentu berdasarkan atas suku, agama, ras, dan antar golongan (SARA).

Berdasarkan undang-undang ITE dijelaskan bahwa berita bohong bertujuan untuk Bertujuan untuk menipu, menimbulkan rasa kebencian atau permusuhan individu dan/atau kelompok masyarakat tertentu berdasarkan atas suku, agama, ras, dan antar golongan (SARA). Tindak pidana penyebaran berita bohong dan menyesatkan termasuk perbuatan yang dilarang yang diatur dalam Pasal 27 Ayat (3) dan Pasal 28 ayat (1), dan ayat (2)Undang-Undang No. 11 Tahun 2008 Jo Undang-Undang No. 19 Tahun 2016 Tentang Informasi dan Transaksi Elektronik. Ketentuan pidana bagi yang melanggar Pasal 27 Ayat (3) terdapat dalam Pasal 45 Ayat (3), sedangkan bagi yang melanggar Pasal 28 Ayat (1), dan (2) terdapat dalam Pasal 45A Ayat (1) dan (2) Undang-Undang No. 19 Tahun 2016 Tentang Informasi dan Transaksi Elektronik Perubahan Atas Undang-Undang No. 11 Tahun 2008 Tentang Informasi dan Transaksi Elektronik.

Pasal 27 Ayat (3) berbunyi : "Setiap Orang dengan sengaja dan tanpa hak mendistribusikan dan/atau mentransmisikan dan/atau membuat dapat diaksesnya Informasi Elektronik dan/atau Dokumen Elektronik yang memiliki muatan Penghinaan dan/atau pencemaran nama baik". Pasal 28 ayat (1) berbunyi : "Setiap Orang dengan sengaja dan tanpa hak menyebarkan berita bohong dan menyesatkan yang mengakibatkan kerugian konsumen dalam Transaksi Elektronik".

Pasal 28 ayat (2) berbunyi : "Setiap Orang dengan sengaja dan tanpa hak menyebarkan informasi yang ditujukan untuk menimbulkan rasa kebencian atau permusuhan individu dan/atau kelompok masyarakat tertentu berdasarkan atas suku, agama, ras, dan antar golongan (SARA)". Pasal 45 ayat (3) berbunyi : "Setiap Orang dengan sengaja dan tanpa hak mendistribusikan dan/atau mentransmisikan dan/atau membuat dapat diaksesnya Informasi Elektronik dan/atau Dokumen Elektronik yang memiliki muatan penghinaan dan/atau pencemaran nama baik sebagaimana dimaksud dalam pasal 27 Ayat (3) dipidana dengan dengan pidana penjara paling lama 4(empat) tahun dan/atau denda paling banyak Rp750.000.000,00 (tujuh ratus lima puluh juta rupiah). Pasal 45A Ayat (1) berbunyi : "Setiap Orang dengan sengaja dan tanpa hak menyebarkan berita bohong dan menyesatkan yang mengakibatkan kerugian konsumen dalam Transaksi Elektronik sebagaimana dimaksud dalam Pasal 28 Ayat (1) dipidana dengan pidana penjara paling lama 6 (enam) tahun dan/atau denda paling banyak Rp1.000.000.000,00 (satu miliar rupiah)." 
Berdasarkan Kitab Undang-Undang Hukum Pidana (KUHP) dan Undang-Undang No.1 tahun 1946 tentang Peraturan Hukum Pidana juga mengatur tentang perbuatan ini.Dalam KUHP menyiarkan kabar bohong di atur dalam Pasal 390 yang berbunyi : "Barang siapa dengan maksud untuk menguntungkan dirisendiri atau orang lain secara melawan hukum, dengan menyiarkan kabar bohong yang meyebabkan harga barang-barang dagangan, dana-dana atausurat-surat berharga menjadi turun atau naik diancam dengan pidana penjara paling lama dua tahun delapan bulan". Pasal 14 ayat (1), ayat (2) dan Pasal 15. Pasal 14 ayat (1) berbunyi : "Barang siapa, dengan menyiarkan berita atau pemberitahuan bohong, dengan sengaja menerbitkan keonaran dikalangan rakyat, dihukum dengan hukuman penjara setinggi-tingginya sepuluh tahun".

\section{Bentuk-bentuk Penyebaran Berita Bohong (Hoax) dalam Aturan Perundang-Undangan di Indonesia}

"Setiap orang berhak untuk berkomunikasi dan memperoleh informasi untuk mengembangkan pribadi dan lingkungan sosialnya, serta berhak untuk mencari, memperoleh, memiliki, menyimpan, mengolah, dan menyampaikan informasi dengan menggunakan segala jenis saluran yang tersedia".

Dewasa ini orang-orang akan cenderung mencari berita melalui internet dari pada media massa konvensional seperti koran, televisi, majalah, radio, dan lain-lain. Terjadinya peralihan ini dikarenakan setiap orang dapat dengan mudah dan tidak membutuhkan biaya yang mahal hanya dengan mengakses berita melalui internet maka berita dari segala penjuru dunia dapat diakses. Selain itu berita yang di muat di internet memiliki kelebihan jika dibandingkan pada isi berita di media massa konvensional. Beberapa keunggulan berita di internet adalah berita yang dimuat lebih up to date, sehingga dapat meliput peristiwa-peristiwa yang penting, dan sumber berita yang lebih banyak (Siti, 2018). Ternyata penyebaran berita bukan hanya di menjadi domain dari media massa konvensional ataupun media onlineatau melalui sms maupun email, tapi juga melalui jejaring sosial seperti facebook, twitter, line, whatsapp, path, instagram dan jenis lainnya (Choiroh, 2017).

Komunitas Anti Hoax yang membentuk Turn Back Hoax menerangkan beberapa cara kerja penyebaran berita bohong (hoax) di antaranya: 1) Berita bohong (hoax) berawal dari rasa kebencian oknum tertentu terhadap tokoh/etnis/instansi, yang selanjutnya dilegitimasi kebenaran isi beritanya dengan meciptakan kebenaran baru sesuai kemauannya; 2) Melalui akun buzzer, berita bohong (hoax) menyebarkan provokasi melalui penggunaan hastag dan permainan akun bot; 3) Selanjutnya diterima oleh konsumen berita yang cenderung sukarela dalam menyukai (like) dan membagikan (share) berita tersebut berdasarkan kepentingan masingmasing atau dikarenakan sebuah kebencian terhadap pihak lain sehingga terkesan bersaing (Regina, 2013).

Penyampaian berita bohong atau berita bohong memanfaatkan hampir semua saluran yang memiliki potensi terhubung dengan banyak orang atau khalayak umum. Hal ini membuat seseorang yang memanfaatkan saluran publik secara otomatis menjadi penikmat atau sasaran penyebaran berita bohong. Pada gilirannya, informasi berita bohong tersebut bisa dalam bentuk berita, informasi sederhana, video, ataupun pesan gambar, dan grafis. Karakteristik saluran informasi publik saat ini yang memberikan kemudahan dalam menyampaikan setiap informasi yang diterima tersebut, membuat pelaku penyebar berita berita bohong lebih leluasa dalam menjalankan aksinya. Hal tersebut ikut dipengaruhi tingkat pemahaman masyarakat Indonesia yang masih rendah tentang jenis-jenis berita berita bohong.

Berdasarkan hal itu, maka dapat disimpulkan bahwa berita bohong yang dapat dikategorikan sebagai tindak pidana terorisme adalah berita bohong yang mengancam keselamatan bangsa dan negara, menimbulkan perpecahan, membuat gaduh di masyarakat. Meskipun tidak termasuk dalam undang-undang terorisme, namun efek yang didapat mungkin 
sama dengan yang dilakukan oleh para terorisme dalam tindak pidana terorisme, meskipun tidak mengancam nyawa banyak orang. Tindak pidana terorisme sendiri dimaknai sebagai tindak pidana yang akan mengancam kehidupan warga negara akan efek teror yang dilakukan oleh teroris.

Berdasarkan argumentasi di atas, maka perbuatan penyebaran berita bohong tentu sangat meresahkan masyarakat. Muncul kecurigaan antara pihak satu dengan pihak lain karena pasti ada yang harus bertanggungjawab terhadap tindak pidana yang dilakukan. Apalagi jika berita bohong itu menyangkut telah terjadinya teror di tengah-tengah masyarakat, sehingga menyebabkan masyarakat menjadi ketakutan, aktivitas ekonomi terhenti yang menyebabkan timbulnya kerugian materil, belum lagi terpecah-belahnya masyarakat akibat berita bohong itu.

Menjadi sebuah keniscayaan, apabila pemerintah dalam hal ini Kepolisian Republik Indonesia menindak tegas pelaku penyebar berita bohong itu. Banyak aturan perundangundangan yang dapat menjerat pelaku penyebaran berita bohong tersebut, sehingga pelakunya dapat dikenakan pasal berlapis, dengan hukuman yang maksimal. Hal ini dilakukan untuk memberikan efek jera bagi pelaku penyebar berita bohong. Kasus penyebaran berita bohong yang ditangani oleh Kepolisian Daerah Sumatera Utara sendiri sebenarnya tidak terlalu banyak, dan penyebaran berita bohong yang terjadi sering kali kontennya adalah SARA. Menurut keterangan yang diperoleh dari informan, di Kepolisian Daerah Sumatera Utara, kasus-kasus yang terkait dengan berita bohong penanganannya telah dilakukan sesuai dengan prosedur yang berlaku di internal kepolisian.

Beberapa aturan perundang-undangan yang berlaku di Indonesia yang dapat menjerat pelaku penyebaran berita bohong, menunjukkan bahwa Negara dalam hal ini telah melindungi masyarakat dari bahaya berita bohong. Kebijakan hukum yang diambil oleh pembuat undangundang dalam rangka melindungi rakyat dari berita bohong harus diapresiasi. Pada sisi lain juga pemerintah juga telah berupaya untuk melakukan tindakan preventif terhadap penyebaran berita bohong. Melaksananakan politik hukum pidana dalam menurut Sudarto berarti mengadakan pemilihan untuk mencapai hasil perundang-undangan pidana yang paling baik, artinya hukum harus memenuhi syarat keadilan dan juga daya guna. Melaksanakan politik hukum pidana artinya berusaha untuk mewujudkan peraturan perundang-undangan pidana yang sesuai dengan keadaan dan situasi pada suatu waktu dan untuk masa yang akan datang ( Sudarto: 1983).

\section{Sanksi Pidana Bagi Pelaku Penyebaran Berita Bohong Ditinjau Dari Aspek Tindak Pidana Terorisme}

Perkembangan kemajuan teknologi saat ini mengarah pada banyak kemajuan di semua aspek, termasuk didalamnya komunikasi yang membuat setiap orang dengan pihak lain tidak perlu saling bertemu untuk berkomunikasi. Aktivitas dunia maya adalah salah satu contoh perkembangan teknologi yang pesat. Setiap orang dapat memasuki dunia virtual yang sifatnya abstrak, universal, bebas dari keadaan, tempat dan waktu. Kemajuan teknologi itu termasuk penemuan interet, yaitu teknologi yang memungkinkan manusia untuk saling bertukar informasi dengan siapa pun dan dimana pun orang itu berada, tanpa dibatasi oleh ruang dan waktu. Internet adalah penemuan spektakuler yang merubah wajah peradaban dunia. Internet adalah penemuan yang pada mulanya berfungsi sebagai alat pertukaran data ilmiah dan akademik, namun sekarang telah berubah menjadi alat kehidupan sehari-hari dan dapat diakses dari berbagai belahan dunia (Haris, 2004)

Perkembangan teknologi informasi dan komunikasi membawa dampak positif maupun negatif, ibarat pedang bermata dua. Pengaruh positifnya berupa pemanfaatan teknologi informasi dan komunikasi di satu pihak memberikan kontribusi bagi peningkatan kesejahteraan dan peradaban manusia. Di lain pihak, kemajuan teknologi Informasi dan Transaksi Elektronik tersebut dapat dimanfaatkan untuk melakukan perbuatan-perbuatan yang sifatnya melawan 
hukum, yang menyerang berbagai kepentingan hukum orang, masyarakat, dan negara (Adami, 2011). Undang-Undang Republik Indonesia Nomor 11 Tahun 2008 tentang Informasi dan Transaksi Elektronik resmi diberlakukan. UU ITE memuat sejumlah peraturan tentang manajemen informasi dan transaksi elektronik di tingkat nasional yang bertujuan agar pembangunan dapat dilakukan secara optmal, merata dan tersebar di semua lapisan masyarakat dalam rangka mendidik kehidupan bangsa (Abigail, 2018).

Kemajuan zaman dan munculnya era globalisasi ternyata mampu mengubah kehidupan masyarakat menjadi lebih maju dan canggih. Kecanggihan ini dapat dilihat pada penggunaan perangkat elektronik yang membentang dari kelas atas sampai kelas bawah. Semua aktivitas masyarakat didukung oleh perangkat elektronik tersebut. Kemajuan zaman yang ada ternyata menimbulkan dua sisi yang saling bertolakbelakang. Satu sisi menimbulkan efek positif yaitu pemakai smartphone dapat mengakses berita dan informasi dengan lebih cepa. Pada sisi lain juga menimbulkan efek negatif yaitu berita atau info yang didapat ternyata berita bohong atau yang dikenal dengan istilah berita bohong. Undang-Undang Nomor 11 Tahun 2008 tentang Informasi dan Transaksi Elektronik mengatur sanksi pidana, terutama mengenai tindak pidana melalui ancaman sanksi pidana yang kekuatannya sangat kuat untuk mengantisipasi penggunaannya yang akan membawa pengaruh buruk dalam memanfaatkan kemajuan teknologi dan transaksi elektronik. Tujuan dari hukum pidana untuk kasus berita bohong adalah untuk menerapkan sanksi pidana terhadap pelaku berita bohong, sehingga memiliki efek jera dan pelaku sera orang lain tidak lagi melakukkannya karena berita bohong tersebut merugikan orang lain dalam cakupan yang luas bahkan negara juga turut dirugikan.

Fungsi hukuman adalah untuk menjamin kehidupan masyarakat yang harmonis dan untuk menghindari perpecahan yang disebabkan oleh kebohongan yang disebarkan (Josua, 2012). Salah satu efek negatif yang sering terjadi karena kemudahan komunikasi dan pertukaran informasi melalui media online di antara sesama pengguna internet adalah informasi atau berita yang didistribusikan secara indivdu atau dalam suatu kelompok tidak dapat diverifikasi kebenarannya atau yang disebut dengan berita palsu/bohong (Gusti:2012). Tindak pidana penyebaran berita bohong dan menyesatkan termasuk perbuatan yang dilarang yang diatur dalam Pasal 27 Ayat (3) dan Pasal 28 ayat (1), dan ayat (2)Undang-Undang No. 11 Tahun 2008 Jo Undang-Undang No. 19 Tahun 2016 Tentang Informasi dan Transaksi Elektronik. Ketentuan pidana bagi yang melanggar Pasal 27 Ayat (3) terdapat dalam Pasal 45 Ayat (3), sedangkan bagi yang melanggar Pasal 28 Ayat (1), dan (2) terdapat dalam Pasal 45A Ayat (1) dan (2) UndangUndang No. 19 Tahun 2016 Tentang Informasi dan Transaksi Elektronik Perubahan Atas Undang-Undang No. 11 Tahun 2008 Tentang Informasi dan Transaksi Elektronik.

Pasal 28 ayat (1) berbunyi : "Setiap Orang dengan sengaja dan tanpa hak menyebarkan berita bohong dan menyesatkan yang mengakibatkan kerugian konsumen dalam Transaksi Elektronik". Pasal 45A Ayat (1) berbunyi : "Setiap Orang dengan sengaja dantanpa hak menyebarkan berita bohong dan menyesatkan yangmengakibatkan kerugian konsumen dalam Transaksi Elektronik sebagaimana dimaksud dalam Pasal 28 Ayat (1) dipidana dengan pidanapenjara paling lama 6 (enam) tahun dan/atau denda paling banyakRp1.000.000.000,00 (satu miliar rupiah)." Pasal 45A Ayat (2) berbunyi : "Setiap Orang dengan sengaja dan tanpa hak menyebarkan informasi yang ditujukan untuk menimbulkan rasakebencian atau permusuhan Individu dan/atau kelompok masyarakattertentu berdasarkan atas suku, agama, ras dan antargolongan (SARA)sebagaimana dimaksud dalam Pasal 28 Ayat (2) dipidana dengan pidanapenjara paling lama 6 (enam) tahun dan/atau denda paling banyakRp1.000.000.000,00 (satu miliar rupiah)."

\section{Kaitan Antara Tindak Pidana Penyebaran Berita Bohong Dengan Tindak Pidana Terorisme.}


Definisi terorisme sampai dengan saat ini masih menjadi perdebatan meskipun sudah ada ahli yang merumuskan dan juga dirumuskan di dalam peraturan perundang-undangan. Akan tetapi ketiadaan definisi yang seragam menurut hukum internasional mengenai terorisme tidak serta-merta meniadakan definisi hukum terorisme itu. Masing-masing negara mendefinisikan menurut hukum nasionalnya untuk mengatur, mencegah dan menanggulangi terorisme (Indriyanto, 2001).

Berdasarkan undang-undang Nomor 15 Tahun 2003 tentang Pemberantasan Tindak Pidana Terorisme, bahwa terorisme adalah perbuatan melawan hukum secara sistematis dengan maksud untuk menghancurkan kedaulatan bangsa dan Negara dengan membahayakan bagi badan, nyawa, moral, harta benda dan kemerdekaan orang atau menimbulkan kerusakan umum atau suasana teror atau rasa tacit terhadap orang secara meluas, sehingga terjadi kehancuran terhadap objek-objek vital yang strategis, kebutuhan pokok rakyat, lingkungan hidup, moral, peradaban, rahasia negara, kebudayaan, pendidikan, perekonomian, teknologi, perindustrian, fasilitas umum, atau fasilitas internasional. T. P. Thornton, terorisme didefinisikan sebagai penggunaan teror sebagai tindakan simbolis yang dirancang untuk mempengaruhi kebijaksanaan dan tingkah laku politik dengan cara-cara ekstra normal, khususnya dengan penggunaan kekerasan dan ancaman kekerasan (Mahrus, 2012).

Berbagai pendapat dan pandangan mengenai pengertian yang berkaitan dengan terorisme diatas dapat ditarik kesimpulan, bahwasanya terorisme adalah kekerasan terorganisir, menempatkan kekerasan sebagai kesadaran, metode berpikir sekaligus alat pencapaian tujuan. Dari berbagai pengertian diatas, menurut pendapat para ahli bahwasanya kegiatan terorisme tidak akan pernah dibenarkan karena ciri utamanya, yaitu: Aksi yang digunakan menggunakan cara kekerasan dan ancaman untuk menciptakan ketakutan publik, Ditujukan kepada Negara, masyarakat atau individu atau kelompok masyarakat tertentu, Memerintah anggota-anggotanya dengan cara teror juga, Melakukan kekerasan dengan maksud untuk mendapat dukungan dengan cara yang sistematis dan terorganisir (Faisal, 2005).

Melihat bagaimana korelasi antara tindak pidana penyebaran berita bohong dengan tindak pidana terorisme, maka perlu dilihat juga karakteristik tindak pidana terorisme. Menurut FX Adji Samekto yang mengutip pendapat James H. Wolfe, menyebutkan beberapa karakteristik terorisme, antara lain sebagai berikut: Terorisme dapat didasarkan pada motivasi yang bersifat politis maupun non politis, Sasaran yang menjadi objek aksi terorisme bisa sasaran sipil (supermarket, mall, sekolah, tempat ibadah, rumah sakit dan fasilitas umum lainnya), maupun sasaran non sipil (tangsi militer, kamp militer), Aksi terorisme dapat ditujukan untuk mengintimidasi atau mempengaruhi kebijakan pemerintah Negara, Aksi terorisme dilakukan melalui tindakan yang tidak menghormati hukum internasional atau etika internasional. Serangan yang dilakukan dengan segaja untuk membinasakan penduduk sipil seperti yang terjadi pada Bom Bali beberapa waktu lalu adalah pelanggaran hukum internasional, Aktivitas teroris menciptakan perasaan tidak aman dan merupakan gangguan psikologis untuk masyarakat, Persiapan atau perencanaan aksi teror bisa bersifat multinasional. Maksudnya, pelaku terorisme dapat dilakukan oleh warga negara itu sendiri maupun oleh warga nagara asing atau gabungan dari keduanya, Tujuan jangka pendek aksi terorisme adalah menarik perhatian media massa dan perhatian public, Aktivitas terorisme mempunyai nilai mengagetkan (shock value) yang bagi teroris bergguna untuk mendapatkan perhatian. Untuk itulah dampak aktivitas terorisme selalu terkesan kejam, sadis dan tanpa menghargai nilai-nilai kemanusiaan.

Beberapa kasus di Indonesia dapat dilihat adanya hubungan antara penyebaran berita bohong yang terkait dengan tindak pidana terorisme atas dasar agama. Misalnya kasus muncul sejumlah laman daring dan akun media sosial yang mencatut nama Nahdatul Ulama dan menyebarkan isu-isu radikalisme serta mendiskreditkan tokoh-tokoh Nahdatul Ulama. Konten laman tersebut berisi informasi negatif mengenai aspek sosio-kultural, sejarah, dan tokoh-tokoh Nahdatul Ulama. 
Pengaturan mengenai pemidanaan permufakatan jahat, percobaan, dan pembantuan untuk melakukan tindak pidana terorisme yang disamakan dengan pelaku tindak pidana terorisme, menunjukkan bahwa pembuat undang-undang menganggap tindak pidana terorisme sebagaimana dimaksud dalam pasal-pasal tersebut di atas sebagai tindak pidana yang sifatnya begitu berbahaya bagi kepentingan hukum baik terhadap orang maupun harta benda.

Apabila dilihat dari beberapa perbandingan antara tindak pidana terorisme dengan tindak pidana penyebaran berita bohong, maka akan ditemukan persamaannya. Persamaan itu antara lain adalah antara tindak pidana terorisme dengan tindak pidana penyebaran berita bohong, efeknya sama-sama menimbulkan keresahan di tengah-tengah masyarakat. Masyarakat dilanda ketakutan yang masif terkait dengan isu yang dihembuskan. Tindak pidana terorisme misalnya efeknya adalah menimbulkan korban jiwa, korban psikologis yang memerlukan waktu untuk pemulihan kejiwaannya, dampak ekonomi bagi sebagian yang lokasi usahanya menjadi sasaran pemboman, munculnya kerugian kepada pihak lain sebagai pelaku pengeboman. Tindak pidana penyebaran berita bohong memberikan efek terhadap perpecahan di masyarakat, terganggunya stabilitas ekonomi, seperti isu kasus telur palsu beberapa tahun yang lalu, muncul kebencian terhadap ras dan agama tertentu.

Adanya upaya beberapa pihak untuk menjadikan pelaku penyebaran berita bohong sebagai pelaku terorisme, mungkin masih memerlukan kajian yang cukup mendalam serta memakan waktu yang lama. Hal ini dikarenakan unsur-unsur pidana antara kedua tindak pidana tersebut tidaklah sama. Efek yang ditimbulkan mungkin juga tidaklah terlalu sama, demikian pula terkait dengan pertanggungjawaban pidana pelakunya. Tindak pidana terorisme sudah masuk kedalam tindak pidana luar biasa (extra ordinary crime) dan sudah dijadikan sebagai kejahatan kemanusiaan yang standarnya sama diseluruh dunia.Tindak pidana penyebaran berita bohong, meskipun menimbulkan efek yang luar biasa juga, namun belum sampai pada titik membahayakan jiwa manusia.

\section{SIMPULAN}

Bentuk penyebaran berita bohong dapat dikategorikan sebagai tindak pidana terorisme, dimana tindak pidana terorisme adalah juga mengancam keselamatan bangsa dan negara, menimbulkan perpecahan, membuat kegaduhan dimasyarakat, meskipun tindakan penyebaran berita bohong tersebut tidak diatur dalam undang-undang terorisme namun menimbulkan efek yang mungkin sama dengan yang dilakukan oleh para terorisme, hanya saja perbuatan penyebaran berita bohong tersebut tidak mengancam nyawa banyak orang. Sanksi pidana bagi pelaku penyebaran berita bohong ditinjau dari aspek tindak pidana terorisme adalah dapat disamakan dengan pemidanaan permufakatan jahat, percobaan, dan pembantuan untuk melakukan tindak pidana terorisme.

\section{DAFTAR PUSTAKA}

Abede, P.S., (2005), Manajemen Berita antara Idealisme dan Realita, Surabaya: Papyrus.

Adji, I.S., (2001), Terorisme dan HAM dalam Terorisme: Tragedi Umat Manusia. Jakarta : O.C. Kaligis \& Associates.

Ali, M., (2012), Hukum Pidana Terorisme Teori dan Praktik, Jakarta: Gramata Publishing.

Asnawi, H.F., (2004), Transaksi Bisnis E-commerce Prespektif Islalm, Yogyakatra: Magistra Insania Press bekerjasama dengan MSI UII.

Chazawi, A., dan Ferdian, A., (2011), Tindak Pidana Informasi \& Transaksi Elektronik, Malang: Bayumedia.

Choiroh, L. U., (199), Pemberitaan Hoax perspektif Hukum Pidana Islam. Al- Jinayah: Jurnal Hukum Pidana Islam, Volume3, Nomor 2.

Choo, C. W., Detlor, B., \& Turnbull, D., (1999)., Information Seeking on the Web-An Integrated Model of Browsing and Searching, dalam ASIS Annual Meeting, Vol. 5 Issue 2 
Hidayat, G., Eddy, T., \& Sahari, A. (2020). Peran Detasemen Gegana Satuan Brimob Polda Sumatera Utara Dalam Penanggulangan Tindak Pidana Terorisme. Journal of Education, Humaniora and Social Sciences (JEHSS), 3(1), 44-51. doi:https://doi.org/10.34007/jehss.v3i1.191

Julani, R, (2017), "Media Sosial Ramah Sosial VS Hoax", dalam Jurnal Program Studi Komunikasi Fakultas Ilmu Sosial dan Ilmu Politik, Volume 8, Nomor 2, 2017.

Librianti, E.O.I. \& Mughni, A, (2019), "Dakwah Melawan Hoax Menuju Literasi Media", melalui http://researchgate.com diakses tanggal 20 Oktober 2019.

Mahardika, Y.R.C., (2017)., Perilaku Mahasiswa dalam Menyikapi Pemberitaan Hoax Di Media Sosial Facebook (Studi pada Mahasiswa Ilmu Komunikasi Universitas Muhammadiyah Malang Angkatan 2013 yang Menerima Pemberitaan Hoax Terkait Isu Corporate Nasional), Jurusan Ilmu Komunikasi, Universitas Muhammadiyah Malang, Malang, 2017.

Nasution, A. (2015). Terorisme di abad ke -21 upaya penegakan hukum terhadap tindak kejahatan terorisme dalam perpektif hukum internasional dan hak asasi manusia. Jurnal mercatoria, 8(1), 5474. doi:https://doi.org/10.31289/mercatoria.v8i1.647

Novitawati, N.P.D., Parman, L., \& Sabardi, L, "Pertanggungjawaban Pelaku Tindak Pidana Penyebaran Berita Bohong (Hoax)", dalam Jurnal Binawakya, Volume 13, Nomor 11, Juni 2019, melalui https://ejurnal.binawakya.or.id/index.php/MBI, diakses tanggal 28 Agustus 2019.

Nugroho, A.S., dan Mursid, F., (2019), “Polisi Dalami Motif Berita bohong Tujuh Kontainer”, dalam Harian Republika, Kamis, 10 Januari 2019.

Octaviyani, P.R., (2019), "Pembuat Berita bohong Ingin Sudutkan Jokowi”, dalam Harian Media Indonesia, Kamis, 10 Januari 2019.

Pinatih, I.G.A.K., \& Suardana, I.W., (2018), "Kajian Yuridis Penyebaran Berita Bohong (Hoax) Di Media Online Ditinjau Dari Aspek Hukum Pidana Indonesia", melalui http://www.academia.edu, diakses tanggal 10 Oktober 2019.

Rahadi, D.R.,, (2007), Perilaku Pengguna dan Informasi Hoax di Media Sosial”, dalam Jurnal Manajemen dan Kewirausahaan, Volume 5, Nomor 1.

Raharjo, A., (2002), Pemahaman dan Upaya Pencegahan Kejahatan Berteknologi. Cet. I., Bandung: PT Citra Aditya Bakti.

Rahmatullah, T., (2018), "Hoax Dalam Perspektif Hukum Indonesia”, dalam Jurnal Hukum Media Justitia Nusantara, Volume 8, Nomor 2, September 2018.

Rasywir, E., \& Purwarianti, A, (2016), Eksperimen pada Sistem Klasifikasi Berita Hoax Berbahasa Indonesia Berbasis Pembelajaran Mesin, Jurnal Cybermatika, Volume 3, Nomor 2.

Remmelink, J, (2003), Hukum Pidana (Komentar atas Pasal-Pasal Terpenting dari Kitab Undang-Undang Hukum Pidana Belanda dan Padanannya dalam Kitab Undang-Undang Pidana Indonesia), Jakarta: Gramedia Pustaka

Ricky Firmansyah, Web Klarifikasi Berita Untuk Meminimalisir Penyebaran Berita Hoax, dalam Jurnal Informatika, Volume 4, Nomor 2, 2017.

Sidiq, N.A. (2017), "Penegakan Hukum Dalam Penanggulangan Berita Palsu (Hoax) Menurut UndangUndang No. 11 Tahun 2008 Yang Telah Dirubah Menjadi Menjadi Undang-Undang No. 19 Tahun 2016 Tentang Informasi Dan Transaksi Elektronik", dalam Lex et Societes, Volume V, Nomor 10, Desember 2017

Siswoko, K.H., (2017)., “Kebijakan Pemerintah Menangkal Penyebaran Berita Palsu atau Hoax”, dalam Jurnal Muara Ilmu Sosial, Humaniora, dan Seni, Volume 1, Nomor 1, 2017.

Sitompul, A., (2004), Hukum Internet Pengenalan Mengenai Masalah Hukum di Cyberspace, Bandung: PT Citra Aditya Bakti.

Sitompul, J, (2012), Cyberspace, Cybercrimes, Cyberlaw Tinjauan Aspek Hukum Pidana, Jakarta: Tatanusa.

Sudarsono, (2007), Kamus Hukum, Cetakan Kelima, Jakarta : PT Asdi Mahasatya.

Sudarto, (1983), Hukum Pidana dan Perkembangan Masyarakat, Bandung: Sinar Baru Algensindo.

Sunarso, S, (2009), Hukum Informasi dan Transaksi Elektronik (Studi Kasus; Prita Mulyasari), Jakarta: Rineka Cipta. 